\title{
ПАРОДИЙНОЕ ВОСПРИЯТИЕ ДЕЙСТВИТЕЛЬНОСТИ У ВИКТОРА ПЕЛЕВИНА (НА МАТЕРИАЛЕ РОМАНА ЧАПАЕВ И ПУСТОТА
}

\author{
VICTOR PELEVIN'S PARODIC PERCEPTION OF REALITY \\ (BASED ON BUDDHA'S LITTLE FINGER)
}

\author{
ВАВЖИНЕЦ ПОПЕЛЬ-МАХНИЦКИ
}

\begin{abstract}
Victor Pelevin, a representative of Russian postmodernism, is known as a careful observer of reality. Postmodern art is characterized by grotesque, pastiche and parody, which is emphasized by many researchers. The analysis of Victor Pelevin's Buddha's Little Finger shows how the writer perceives the times of the Soviet Union as well as the post-Soviet reality in which Russia embarked on the path of capitalist development. The parody used in the novel allows the reader to see if Pelevin only wants to ridicule his country in a shocking way or rather aims to repair the reality with his own literary works.
\end{abstract}

Wawrzyniec Popiel-Machnicki, Uniwersytet im. Adama Mickiewicz w Poznaniu, Poznań - Polska.

Почти 70 лет минувшего века граждане Советского Союза, существовавшего с 1922 года по 1991 год, жили в вере в возможность рая на земле, рая, предназначенного для его строителей. В советской России для всех была работа, строились дома, школы, фабрики и прочее, население все время получало информацию о полном успехе во всех отраслях жизни. Однако эта, казалось бы, превосходная действительность оказалась обманчивой. „Советский мир был настолько абсурден и продуманно нелеп, что принять его за окончательную реальность было невозможно даже для пациента психиатрической клиники" 1 . Люди осознали, что жить так дальше невозможно. И, как замечает Данила Ланин,

взамен непереносимой реальности, где были только пустота, презрение к самим себе и ясное понимание того, что твоя собственная жизнь - не жизнь, а скверная пародия, возник „внутренний мир” русского интеллигента. Став обитателем этого мира, можно было жить дальше, и при этом чувствовать

${ }^{1}$ В. П е л е в и н, Джон Фаулз и трагедия русского либерализма, [в:] его же, Relics. Раннее и неизданное, Москва 2005, с. 338. 
себя даже более „внутренне цивилизованным”, чем любой европеец, ибо цивилизация теперь свелась к культуре мысли и чувства. Уметь мыслить, уметь чувствовать - означало уже жить².

Советский Союз оказался сюрреалистической страной, в которой граждане необходимость повседневного выживания совмещали с постоянно звучавшими вечными духовными вопросами, пропитанными в коммунистические времена уродливо-пародийной политической идеологией. Сторонник жизни в СССР, так называемый совок,

влачил свои дни очень далеко от нормальной жизни, но зато недалеко от Бога, присутствия которого он не замечал. Живя на самой близкой к Эдему помойке, совки заливали портвейном „Кавказ” свои принудительно раскрытые духовные очи, пока их не стали гнать из вишневого сада, велев в поте лица добывать свой хлеб

Россия вернулась к периоду капиталистической экономики, который оборвался в итоге большевистского переворота. Последние десятилетия показали, что попытка наверстать утраченное время привела к внедрению в жизнь наиболее жестокой формы капитализма.

Россия - это страна, в которой художественная литература всегда занимала чрезвычайно важное место, позволяя отвлечься от нередко угнетающих сложностей жизни. Множество людей, которым пришлось смириться с повседневной суетой, решили поделиться своими опытом и волнениями, представляя их в форме литературной исповеди. Это и была "«внутренняя свобода» - один из краеугольных камней той удивительной призрачной цивилизации, которую создала русская интеллигенция" 4 . Для писателей, представляющих официальную литературу, а также для тех, кому пришлось уехать в эмиграцию, слово являлось мощной силой, существенной как для агитации, так и для пародирования несходного с их миропониманием окружения. Стоит здесь вспомнить о соцреализме, Самиздате и Тамиздате, наложивших определенный отпечаток на сознание читателей. Могло бы показаться, что после перестроечных изменений значение литературы уменьшилось. Ее место заняло телевидение и Интернет. Конечно, литература не исчезла, но она подверглась всеобщей коммерциализации. В книжных магазинах России преобладает сегодня примитивная фантастика, тривиальные детективы и модная новая эссеистика. Среди этого т.н. чтива, к счастью, встречаются высокохудожественные произведения, которые вписываются в постмодернистское искусство.

2 Д. Л а н и н, Виктор Пелевин и пустота российского самосознания, [электронный pecyрс:], http://pelevin.nov.ru/stati/o-pchp/1.html (25.08.2012).

${ }^{3}$ В. П е л е в и н, Джон Фаулз..., указ. соч., с. 339.

4 Д. Л а н и н, Виктор Пелевин и пустота..., указ. соч. 
Согласно Сергею Корневу, „постмодернизм - это игра на грани стеба", а стеб означает пародию, гротеск ${ }^{5}$. Борис Дубин определяет стеб как

разновидность публичного интеллектуального эпатажа, который состоит в провокационном и агрессивном, на грани скандала, снижении любых символов других групп, образов прожективных партнеров - как героев, так и адресатов сообщения - через подчеркнутое использование этих символов в несвойственном им, пародийном или пародическом контексте, составленном из стереотипов, как минимум, двух разных лексических и семантических уровней, рядов ${ }^{6}$.

Теоретических определений постмодернизма довольно много. Ученые обращают внимание на различные признаки этого современного искусства, подчеркивая их дифференциальное значение.

Так, например, - утверждает Корнев, - не обрисовывает сущность постмодернизма злоупотребление цитатами, явным и косвенным цитированием, когда обыгрывание фрагментов чужой речи становится одним из ключевых компонентов собственной. Опора на цитаты, на фиксированный ряд сюжетов и тем, на образцовые произведения прошлого, когда суть не в новизне сюжета, а в новизне исполнения, сочленения, обработки - это состояние любой развитой устоявшейся культуры ${ }^{7}$.

Цитирование, пастиш, коллаж или интертекстуальность свойственны не только постмодернизму, но и литературе вообще. Об этом писал уже Михаил Бахтин, анализирующий творчество Федора Достоевскогов. В постмодернизме ссылки на других авторов являются более осознанным литературным приемом. Суть постмодернизма даже не всегда в стебе. Если писатель-постмодернист не ставит на эпатаж, если мы не знаем, пишет ли он в данный момент всерьез, то появляется ощущение пародии, или даже пародии на пародию.

Писателем, который принадлежит к русскому постмодернизму, является Виктор Пелевин. Причисляя Пелевина к большому искусству, Корнев подчеркивает, что писатель - высшая стадия постмодернизма или, точнее, новый этап словесности, именуемый „русским классическим пострефлекторным постмодернизмом"9. Такая оценка связана со

${ }^{5} \mathrm{C}$. К о р н е в, Столкновение пустот: может ли постмодернизм быть русским и классическим? Об одной авантюре Виктора Пелевина, „Новое Литературное Обозрение" 1997, № 28, с. 244-259, [электронный ресурс:], http://pelevin.nov.ru/stati/okrn2/1.html (05.09.2012).

6 Б. Д у б и н, Слово - письмо - литература. Очерки по соииологии современной культуры, Москва 2001, с. 163.

7 С. К о р н е в, указ. соч.

${ }^{8}$ М. Б а х т и н, Проблемы творчества поэтики Достоевского, Киев 1994, с. 187.

${ }_{9}$ С. К о р н е в, указ. соч. 
стилем Пелевина, в котором читатель найдет смешение различных литературных форм. Писатель часто „использует постмодернистский прием палимпсеста - создание собственных текстов с активным использованием фрагментов чужих" с отпечатком откровенно пародийного характера ${ }^{10}$.

Пародия, - как подчеркивает Юрий Тынянов, - в истории литературы сказывается не только явлениями пародийных жанров, не только, так сказать, готовыми пародиями, но пародия является и процессом, пародийное отношение к литературной системе вызывает целый ряд аморфных, не окристаллизовавшихся литературных явлений. Эти явления прикрепляются к какой-либо литературной личности, нанизываются на нее, циклизуются вокруг нее ${ }^{11}$.

В контексте этих слов постараемся ответить на вопрос, является ли Пелевин пародистом новой русской действительности.

Нет никакой уверенности, что прозу Пелевина будут читать в будущем, но самое важное, что его книги живут сейчас и играют важную роль в современной русской литературе. Автор Generation П является великолепным пародистом современности, и в его произведениях дана оценка не только вымученного социалистического рая, но прежде всего потребительского стиля жизни, в том числе гламурного стиля поведения сегодняшнего общества. Стоит здесь обратить внимание на пародическое отношение писателя к прошлой эпохе. Примером могут послужить космические завоевания, которые были бесспорным достижением советского периода. Но Советский Союз распался, и все кончилось, а Пелевин-постмодернист сразу же посвящает повесть Омон Рa (1992) „Героям Советского Космоса”. Читая эту ироничную, с дозой цинизма книгу, читатель сразу же вспоминает произведение советского реализма: Повесть о настоящем человеке (1947) Бориса Полевого. Омон Ра - это пародия на официальную литературу минувшей эпохи. Социалистической лжи и тирании писатель противопоставляет внутреннюю свободу, которую каждый человек может найти в собственном внутреннем мире.

Более строго, однако, осуждает автор Омон Ра постсоветскую действительность. Западный образ жизни совершенно разрушил и без того еле тлящуюся мораль и духовные ценности. Пелевин подчеркивает онтологический кризис современности, в которой, учитывая новейшую историю и технократический бум, затерялось русское общество. Герой Пелевина не всегда выступает в роли обыкновенного человека.

10 С. Н е к р а с о в, Субъективные заметки о прозе Виктора Пелевина, [электронный ресурс:], http://pelevin.nov.ru/stati/o-nekr/1.html (08.09.2012).

11 Ю. Т ы н я н о в, О пародии, [в:] его же, Поэтика. История литературы. Кино, Москва 1977, с. 303. 
Он может быть насекомым, зверем, вампиром и т.п. Для писателя важно, чтобы показать человека вне истории, вне моральных норм - человека, который очутился в собственной пустоте, подвергаясь деградации. Человек теряет свою индивидуальность и растворяется в своих иллюзорных ролях.

Хорошим примером конца большой русской идеи и пустоты потребительской современности является книга Чапаеђ и Пустота (1996). Пелевин решил написать роман, употребляя прозаизмы на грани фени, а также используя одновременно псевдоисторизм в форме анекдота. Он рассчитывал шокировать читателя, и это у него, в какой-то степени, получилось. Исходной точкой для пародии Пелевина стал написанный в 1923 году роман о Василии Чапаеве, авторства Дмитрия Фурманова. Обращаясь к Достоевскому, а точнее к старцу Зосиме из Братьев Карамазовыx, Пелевин делает из красноармейского командира мыслителя, который, не отказываясь от алкоголя и наркотиков, ведет со своим учеником, молодым поэтом Петром Пустотой, философские беседы. Необходимо напомнить, что в России Чапаев стал настоящим героем наподобие героев народного фольклора. В противовес этой гиперболизации в общественном обиходе на тему Василия Ивановича появилось множество примитивных и зачастую пошловатых анекдотов. Пелевин, обращая внимание на этот аспект, решил найти в истории большевистского героя, в книге представленного явно пародийно, своего рода мистическую сущность, что разрешило писателю осуществить художественный замысел суровой оценки с ума сходящей постсоветской действительности.

Это позволяет обратить внимание и на то, что в произведении Пелевина находится также явная ссылка на Палату № 6 Антона Чехова, который под конец XIX столетия в контексте больничного отделения для душевнобольных показал срез или фрагмент русского общества. Действие пелевинского повествования происходит переменно в послереволюционной России и в 90-е годы XX века, причем тоже в больнице для сумасшедших. Это возможно потому, что главный герой романа Петр Пустота страдает шизофренией, которая „позволяет” ему перемещаться во времени. Он даже перестает задумываться, какая действительность является более реальной: та, что в психиатрической больнице, или та, что в батальоне Чапаева. Петр знает только, что у полководца ему интереснее, так как там (что для каждого человека очень важно) духовный аспект все время актуален. Большевистский командир - великий мистик и знаток дзен-буддийской философии - помогает Петру Пустоте узнать все об окружающем мире. Он готов ответить Петру на любой вопрос, а итоги этой науки близки солипсизму - радикальному убеждению, что вся вселенная является проекцией того, что творится в нашем сознании. 
Пелевин не намерен убеждать читателя в буддийском или солипсическом понимании мира как иллюзии. Реальность психиатрической больницы - это действительность, которую мы найдем в СМИ. При посредничестве телевидения мы получаем информацию и часто не до конца верим в ее реальность. Дело не только в телевидении. Пелевин предлагает нам такое разнообразие, которое напоминает сегодняшний Интернет. Когда мы пересматриваем сайты всемирной сети, то сталкиваемся с интересными и полезными темами. В Интернете, к сожалению, имеется много сообщений, содержание которых нередко сомнительное. Очень часто в Сети встречается обыкновенный интеллектуальный мусор. В Чапаеве и Пустоте читатель столкнется в сюжете и с информациями, в которые трудно поверить.

Пациенты психиатрической больницы, в которой из-за зависимости от кокаина очутился Петр, получают от врача Тимура Тимуровича (здесь пародийная насмешка на книгу Аркадия Гайдара Тимур и его команда, 1940), заведующего психушкой, своеобразное объяснение:

Ну вот видите. Вы как раз принадлежите к тому поколению, которое было запрограммировано на жизнь в одной социально-культурной парадигме, а оказалось в совершенно другой ${ }^{12}$.

Из этой фразы вытекает следующее: поколение Чапаева боролось за лучшее будущее, а оказалось, что большевики создали для себя и для русского общества ад коммунистической тирании. Конец СССР и ликвидация старой политической системы должны были изменить Россию. Тем временем перестройка привела к общественной шизофрении и расшатыванию системы ценностей, на которых воспитывались очередные поколения. В больнице Тимура Тимуровича мы встречаем именно представителей этого пострадавшего общества.

Рядом с Петром Пустотой Пелевин рисует портрет молодого мужчины, который отождествляется с героиней мексиканского телесериала Просто Мария. Представляющийся именем именно этой героини, метросексуальный мужчина в своем больном сознании встречает Арнольда Шварценеггера, с которым летает ночью над городом на самолете „Харрер”. Гротескный сюжет усиливается здесь сексуальным подтекстом, который подчеркивает пародийность содержания.

В главе про Семена Сердюка - очередного пациента больницы - проглядывает двусмысленность черного юмора. Герой - это алкоголик, который покалечил себя разбитой бутылкой. Однако свой поступок он объясняет потребностью или необходимостью сделать ритуальное „харакири" с целью получения работы в японской фирме. Пелевин в этой истории предвидел проблемы людей, которым в новой эконо-

12 В. П е л е в и н, Чапаев и Пустота, Москва 2007, с. 54. 
мической обстановке пришлось функционировать в корпоративной среде.

Следующая картина - это рассказ о попытке объяснения, что такое „вечный кайф”. У Тимура Тимуровича появляется больной, который, захотев осуществить свои мечты, решил вместе с друзьями погрузиться в наркотический трип. Галлюциногенные грибки приводят к психическому заболеванию.

Такая комиксная конструкция романа нивелирует возможность однозначной интерпретации. Пелевин старался оценить постсоветскую действительность без наличия атрибутов, которыми пользовались классики: Толстой и Достоевский. В книгах автора Generation П религия и философские течения смешиваются со снами и галлюцинациями, усиливая ощущение пародийности. Такой вид пародии, как утверждает Тынянов, носящий „в своей структуре характер комического сдвига систем, оказывается каким-то ценным, устойчивым материалом"13.

Следует помнить, что мистицизм, духовность, православная религия были почти полностью уничтожены коммунистами. Несколько десятилетий веры в атеизм (т.к. атеизм является тоже верой) привели к тому, что перед молодым поколением 90-х годов XX века появилась возможность, а может быть, и необходимость заново открывать для себя религию. Оказалось, что в поисках своего вероисповедания не всегда учитывались верования предков. С христианством начали соперничать другие религии.

В 1979 году в России была издана книжка Исэ моногатари ${ }^{14}$, которая пользовалась большим успехом среди интеллигенции. Буддизм и философия дзен - это та часть духовности, которой необходимо посвятить иногда всю жизнь: постижение дальневосточных тайн не является легким. Пелевин знает об этом и поэтому, не затрагивая в своей книге христианских мотивов, не пытается одновременно слишком серьезно говорить о буддизме.

Цель этих историй - деконструкция внешнего мира, всех социальных норм и предрассудков, и прежде всего - всех конкурирующих идеологий и религиозных догматов ${ }^{15}$.

Делая из героя революции и поэта-декадента буддистов, Пелевин высмеивает не религии, а реалии, в которых пришлось им жить.

Автор Чапаева и Пустоты обеспокоен тем, что наркотики сыграют такую же негативную роль в процессе поисков современным молодым

13 Ю. Т ы н я н о в, указ. соч., с. 299.

14 Исэ моногатари, перевод и комментарии Н.И. Конрад, Москва 1979.

15 С. К о р н е в, указ. соч. 
поколением собственной духовности, как сыграл в свое время алкоголь, ставший для граждан Советского Союза „убежищем” от большевистской идеологии и отгородивший их от религии.

Конец XX столетия оказался сферой пустоты. „Русская идея” стала лишь годиться для рекламы спиртных изделий. Такой недостаток веры в будущее подчеркивает фантасмагория заключительной сцены книги: Чапаев вместе с Петькой едет на броневике, на верхушке башни которого вместо пулемета виднеется глиняный левый мизинец будды Анагамы. Они поражают врагов из глиняного пулемета, а все, во что они целятся, получает свой подлинный облик, то есть превращается в пустоту, названную в книге "условной рекой абсолютной любви”, в сокращении - „Урал"16.

Легендарный командир тоже закончил свою жизнь в реке Урал. Одним словом, эпилог произведения Пелевина довольно пессимистичен - мир должен исчезнуть. Без глубоких идей, в которые могли бы поверить очередные поколения жителей России, существовать нельзя.

Здесь следует согласиться со Станиславом Гуриным, который пишет, что „через смех очень просто скатиться к скепсису, цинизму и нигилизму". Дальше, однако, критик утверждает,

что за иронией и гротеском, сатирой и пародией Пелевина скрывается автор с чувствительным сердцем, нежной и ранимой душой. На самом деле, Пелевин - романтик, он верит в добро и любовь. Его смех жестокий и горький, но это смех сквозь слезы и даже от самых мрачных его произведений у читателя остается светлое впечатление ${ }^{17}$.

Эти слова точно оценивают как Пелевина, так и его творчество, в котором мы находим не только примеры постмодернистского искусства, но и, прежде всего, заботу писателя о своей родине. Таким образом, пародия в романе Пелевина выполняет исключительно положительную рольь.

16 В. П е л е в и н, Чапаељ и Пустота, указ. соч., с. 442.

17 С. Г у р ин, Пелевин между буддизмом и христианством, [электронный ресурс:], http://pelevin.nov.ru/stati/o-gurin/1.html (09.09.2012). 